International Journal of Social Science And Human Research

ISSN(print): 2644-0679, ISSN(online): 2644-0695

Volume 04 Issue 12 December 2021

DOI: $10.47191 / \mathrm{ijsshr} / \mathrm{v} 4-\mathrm{i} 12-24$, Impact factor-5.586

Page No: $3630-3639$

\title{
Implementing a Program on Poly- / Multiculturalism for Future Teachers of Foreign Languages: Practice-Oriented Approach
}

\author{
Oksana Chaika (Čajka)
}

National University of Life and Environmental Sciences of Ukraine, 15, Heroyiv Oborony St., Kyiv 03041, Ukraine

\begin{abstract}
The article considers the key aspects for implementation of a university program on poly- / multiculturalism for future teachers of foreign languages (FL), teachers / instructor of languages for specific purposes (LSP), lecturers and teachers of translation, aiming at the practical value. The two concepts 'polycultural education' and 'multicultural education' are differentiated; it is substantiated that more research is required and the clarifications are to be introduced among academics locally and globally as the mentioned concepts and relevant labels in terminology are misused / confused in the research works laid out in Ukrainian and Russian. Next, the course "Poly- / multiculturalism for future teachers of foreign languages" aims at mastering pedagogical innovations in the field of poly- / multicultural education, development of students' ethno-cultural competence and pedagogical creativity, respectively. The purpose of the optional / specially designed is to form students' ideas about cultural pluralism as an objective social reality and nurture such ideas in support for everyday communication inside and outside the classroom. It is found relevant to single out the following course objectives: 1) to develop poly- / multicultural and ethno-pedagogical competences of students who are training to become FL teachers / instructors, LSP teachers / instructors, translation lecturers, philologists, translators, etc.; 2) to form the students' ability in future to conduct professional activities in a poly- / multicultural environment, taking into account the peculiarities of the socio-cultural situation of development; 3 ) to keep developing the students' ability to use in professional activities the basic development laws of the modern social and cultural environment. It is specified that the course designs the cornerstones by highlighting the relevance in the modern global and educational environment; aim and objectives; the contents; the structure; and the methodology of the course. It is concluded that the research findings contribute to good practices of designing and developing university curricula from a practice-oriented perspective and help bring quality change to the modern educational space.
\end{abstract}

KEYWORDS: Multiculturalism, Polyculturalism, Optional Course, Teachers of Foreign Languages (FL Teachers), LSP Teachers, Teachers of Translation.

\section{INTRODUCTION}

Becoming trendier as it is, the integration of poly- / multiculturalism as a learning component into the university curricula may help enhance quality of the modern education in the connection to its structure and content. Next, of pivotal importance is designing and implementing curricula to train high-class specialists in foreign language instruction and that of languages for specific purposes provided that the courses are delivered in a language other than the mother tongue. It is a combination of hard skills and soft skills for the $21^{\text {st }}$ century, which may help educate future leaders in their respective areas $[21 ; 27 ; 31]$. Thus, study of linguistic phenomena in their close relationship to culture of the people, which language is studied, may explain how growing poly- / multiculturalism would influence the global mobility, including intellectual migration of experts who may contribute to the sustainable growth both in their country and abroad $[32 ; 34 ; 41 ; 43]$. The experience of poly- / multicultural communication, based on bringing up tolerance and acceptance of the unique and/or absorbing something new as the universal, can happen in international classrooms, as well as in classrooms of foreign language acquisition / translation, for example; in the classroom, in which a modern teacher / instructor of a foreign language (FL) or language for specific purposes (LSP) taught in a foreign language, may by example demonstrate appropriate attitude and share the vision of respect towards the others, integrity, acceptance of values that are part of others; in which relevant topics are discussed as part of training skills in listening and reading comprehension, writing and speaking in a foreign language $[13 ; 36 ; 39]$.

Topicality of the issue links to the focus on the internationalization of modern higher education in the context of globalization processes, and enhances the interaction of languages and cultures, which makes it necessary to develop students' ability to effectively realize themselves in professional contexts at the level of poly- / multicultural development $[1 ; 4 ; 6 ; 20]$.

This requires well-developed foreign language communication skills and personality-behavioral qualities, including the ability of a poly- / multicultural individual: (i) to understand the views and content of actions of other cultures, (ii) adjust their 


\section{Implementing a Program on Poly- / Multiculturalism for Future Teachers of Foreign Languages: Practice-Oriented Approach}

behavior to avoid and overcome conflicts, and (iii) ensure effective communication, recognition of the right to the existence of different values and norms in their linguistic and behavioral nationally specific forms of expression.

The purpose of the article is to reveal the content of a university deliverable optional course on the upbringing / fostering poly- / multiculturalism for future teachers of foreign languages in the holistic educational process of modern higher educational establishment.

\section{METHODOLOGY AND LITERATURE REVIEW}

As regards the research methodology, accounting for the nature of the paper, in the course of the study the following methods and techniques were used:

(i) The analysis of scientific literature and available university curricula, which contain the poly- / multicultural component for education;

(ii) Synthesis, used in general theoretical and applied aspects of the research;

(iii) Descriptive method, to demonstrate the key points in the program as discussed under the research topic; etc.

In philosophical research, intercultural interaction is defined as a complex contradictory and ambivalent characteristics of modernity, which Bushkova (2001) determines as a combination of many components and thus, this complex depends on the influence of a number of systemic factors, in particular: socio-political, ideological-axiological, historical-hereditary, culturalcivilizational, stereotypical, etc. [10, p. 5].

Today, it is not only the ideological framework which distinguishes polyculturalism and multiculturalism, that attracts attention of many scholars and researchers, but also the questions deriving from polyculturalism and multiculturalism in their intersection with the educational focus $[9 ; 14 ; 15 ; 23]$.

The globalizing world is changing fast. Efficiency remains questioned in terms of meeting the educational demand, inasmuch internet, media, a great number of and variety in online educational platforms and programs cast challenges for university programs and start competing for the learning audience irrespective of geography, whether it is Ukraine or any other country outside.

To be more specific, many researchers have already significantly contributed to the study of poly-/ multicultural education. Different concepts are analyzed, and the findings speak of a need in further research. For instance, significant theoretical contribution of poly-/ multicultural education reveals in the works by Abibullaeva, Antoniuk, and Byram [16; 3; 12]. Thus, Abibullaeva (2006) underlines the overseas significant experience in polycultural education as such having been accumulated in the U.S. pedagogy. Given that the United States of America is a multinational state, and according to Dovhan and Dovhan (2016) the US ideology for two centuries has been the creation of a single nation, the paradoxical reading comes to either confusing or non-differentiating between the concepts of polycultural and multicultural education, oftentimes attributing properties and characteristics of the multicultural education to the polycultural one or vice versa [16]; for example, "polycultural education, in the U.S. understanding, is education that aims at preserving and developing all cultural diversity values, norms, patterns and forms of activity that exist in a given society, and passing this legacy on to the younger generation" [16, p. 215]. Antoniuk (2004) complements the theoretical study of polyculturalism with ideas on value orientations in the light of polycultural or intercultural educational framework inside and outside Ukraine, Byram (1997) profoundly dwells on teaching and assessing intercultural communicative competence in the multilingual world [3; 12]. More theoretical research by Berry and Kalin (1995), Tanaka (2002), Dandy and Pe-Pua (2010).etc. demonstates that the issue is topical and deserves the academic focus $[9 ; 39 ; 14]$.

At the same time, another vector in the polycultural education is developing fast. The researchers - Bogin, Benedict, Vereshchagin, Kostiushko, Pozhydaieva, Bakum, Yatsikevichus, etc., substantiate concepts of language personality and the second language personality $[42 ; 25 ; 29 ; 5]$.

Modern domestic research is devoted to the study of poly- / multicultural education in line with that of intercultural interaction, in particular: polylingual development as a person's individual development in intercultural polylogy (Bekh) [8]; planetary education of personality (Zelenov); socialization of personality in the context of cross-cultural processes (Seiko); prospects for the development of modern higher foreign language education in Ukraine and the countries of the Council of Europe (Tadeeva) [38]; formation of language personality in the European socio-cultural educational space (Makhinov); problems of language and intercultural interaction (Batsevych, Demetska, Myropolska, Pomirko, Paslavska, Selivanova, Skubashevska) [6; 34; 35]; education of generally accepted cultural and spiritual values and meanings (Shevchenko) [36].

Given the requirements for today's specialists, teachers of modern foreign languages and languages for specific purposes and/or translation (i.e. FL teachers, LSP teachers), there is a need for comprehensive process design for education of poly- $/$ multicultural students who train to make into future philologists, language teachers / instructors, translators. However, this issue remains largely open, because general as opposed to professional specific features of this activity are the focus of modeling the process of becoming a poly- / multicultural personality. 


\section{Implementing a Program on Poly- / Multiculturalism for Future Teachers of Foreign Languages: Practice-Oriented Approach}

\section{RESULTS AND DISCUSSION}

Following the research findings in the last quarter of a century, polycultural education arises twofold. On the one hand, it associates with the acquisition of knowledge and communication skills in a diversified world, and on the other, with the corresponding education to deliver this knowledge to society. Next, it links to the transfer of more accurate and perfected information worthwhile respecting ethnic groups and other minorities, dealing with bias and overcoming such bias and prejudices, and at the same time, to encouraging tolerance. In education, it results in diversified curricula and improving academic achievements of students from minority groups. Overall, it promotes the achievement of ideals for democracy and pluralism [16, p. 215].

Polycultural education as part of pedagogical efforts may ensure cultural and social identification of personality, which easily opens up to other cultures, respects different nationalities, feels tolerant to other races and peoples' beliefs [4; 5; 19; 24].

To enhance effectiveness of upbringing / fostering poly- / multiculturalism for future foreign language teachers, LSP instructors and teachers of translation from a practical perspective, it is relevant as due to establish a set of defined conceptual framework, including principles, goals, objectives, forms, methods and pedagogical conditions. Dovhan and Dovhan determine that the content of polycultural education, however, further in their paper using the English term of 'multicultural education', is built around four guidelines. These include:

(i) Socio-cultural identification of the individual;

(ii) System development of concepts and ideas about the polycultural environment;

(iii) Education of positive attitude to the diversified cultural environment;

(iv) Development of social communication skills [16].

Besides, the authors stress that the main principle of polycultural education is development of cross-cultural abilities that allow young people to adapt to different cultural environments [16, p. 215-216].

It is followed that all the four aspects are crucial for growing a polycultural personality. However, it is seen urgent and burning to draw attention to the misconcept or misusage, or confusion, or synonymous and, thus, substitute usage of the terms 'polycultural education' and 'multicultural education'.

It refers to the above paper, which finds out the following:

UA У ході теоретичних досліджень у США були розроблені дві основні концепції - Multicultural education полікультурної освіти і Global eduсаtion - глобальної освіти, які мали багато спільного (U khodi teoretychnykh doslidzhen' u SSHA buly rozrobleni dvi osnovni kontseptsiyi - Multicultural education - polikul'turnoyi osvity (1) i Global education hlobal'noyi osvity (2), yaki maly bahato spil'noho).

EN In the course of theoretical research, the United States developed two main concepts - Multicultural education multicultural education and Global education - global education, which had much in common [16, p. 216].

As it is outlined in the paper citation, in Example 2 the English term and its Ukrainian translation coincide in concept, although professional translators from English to Ukrainian would argue adoption of meta-phrase (literal translation, or word-byword translation) as the translation technique used. Strange as it is appears, Example 1does not only display arguable translation into Ukrainian, but also misleads the reader by confusing concepts of multicultural education and polycultural education.

Similarly to above examples and the misusage of terminology in the pedagogical studies, Sidun (2012) summarises that in her paper "about the historical development of polycultural education in the USA as well as the periods of its formation, the events, which influenced the drawing up of new curricular, aimed at forming a person with creative and free thoughts who would meet the requirements of a policultural society, are highlighted", meaning multicultural education rather than polycultural [37, p. 148-150]. Such approach to discussion resulting in the wrong translation or substitute of terms 'polyculturalism' and 'multiculturalism' is not rare in the academic papers in Ukraine and post-Sovietic territory, especially where the languages of discussion are Ukrainian and Russian.

Therefore, it was decided to highlight the problematic issues in the Ukrainian pedagogical schools today by bringing that to the top and seek sound critique as to the theoretical and practical value of the course as an optional in the university curriculum for master students, in particular. Next, it was decided to title it "Poly-/Multiculturalism for future teachers of foreign languages", stressing out that the two sides are significant - polycultural and multicultural education, and a free will of a personality should be respected and followed.

It means that the students after completing the course may be well aware what underlies polyculturalism and multiculturalism, and can demonstrate all kinds of tolerance irrespective of the specific ideology in their (inter)national classrooms.

Poly- / multicultural education is an important part of modern education, which contributes to the acquisition of knowledge about other cultures. Poly- / multicultural education clarifies the general and special in the customs, traditions, way of life, and cultural values of peoples. The main goal is to educate the young people in a way that it is so natural to respect inocultural systems.

The course "Poly- / Multiculturalism for future teachers of foreign languages" (Poly- / Multiculturalism for future FL teachers) aims at mastering pedagogical innovations in the field of poly- / multicultural education, development of students' ethnocultural competence and pedagogical creativity (see Fig. 1). 
Fig. 1. Aims of the course on

"Poly- / Multiculturalism for future teachers of foreign languages"

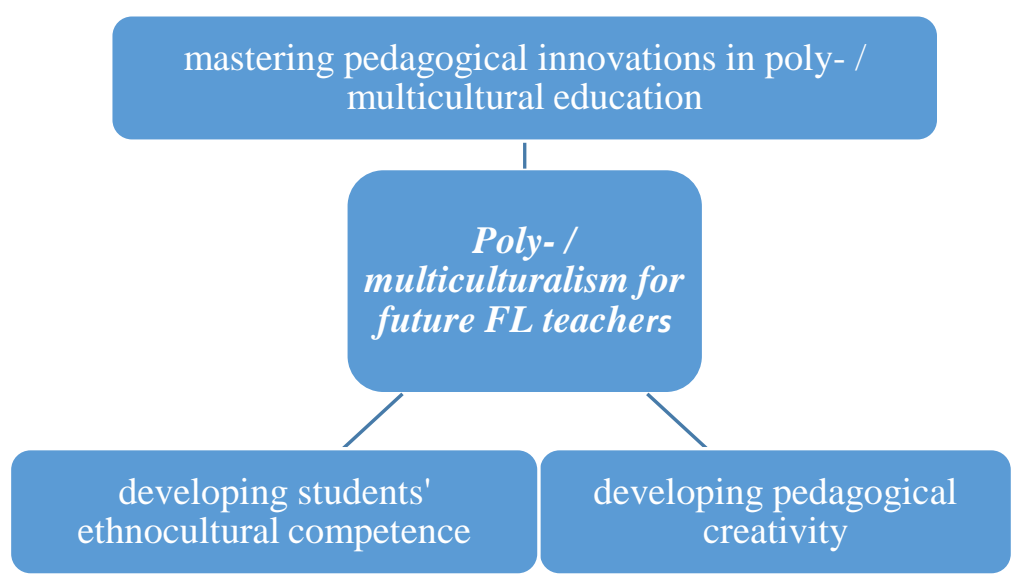

The purpose of the optional / specially designed course "Poly- / multiculturalism for future teachers of foreign languages" is to form students' ideas about cultural pluralism as an objective social reality and nurture such ideas in support for everyday communication inside and outside the classroom.

The objectives of the optional course "Poly- / multiculturalism for future teachers of foreign languages" are as below:

1) To develop poly- / multicultural and ethno-pedagogical competences of students who are training to become FL teachers / instructors, LSP teachers / instructors, translation lecturers, philologists, translators, etc.;

2) To form the students' ability in future to conduct professional activities in a poly- / multicultural environment, taking into account the peculiarities of the socio-cultural situation of development;

3) To keep developing the students' ability to use in professional activities the basic development laws of the modern social and cultural environment.

In addition, it is important to specify the design of the course (see Fig. 2).

Fig. 2. Schemata for "Poly- / multiculturalism for future teachers of foreign languages" course

\section{(a) Relevance of the designed course}

(b) Aim and objectives

(c) Content plane of the course

(d) Structure of the course

(e) Methodology

Fig. 2 for "Poly- / multiculturalism for future teachers of foreign languages" course visualises and designs the cornerstones of the course, by highlighting:

(i) the relevance of the course in the modern global and educational environment, in particular, and discussed in the beginning of the paper;

(ii) aim and objectives (presented afore);

(iii) the contents as to be presented below;

(iv) the structure of the course, also to be delivered in more detail below; and

(v) the methodology of the course, slightly mentioned under the present findings and discussed in other publications with the thorough overview of numerous ways and deliverables. 
Thus, as per (iii) and (iv) it is believed that it is relevant and advisable the contents plane of the optional course "Poly- $/$ multiculturalism for future teachers of foreign languages" includes seven sections: five sections refer to specially designed topics, a section on individual performance and another on facilitation, correspondingly (see Fig. 3).

Fig. 3. Structure of the course on "Poly-/ multiculturalism for future teachers of foreign languages"

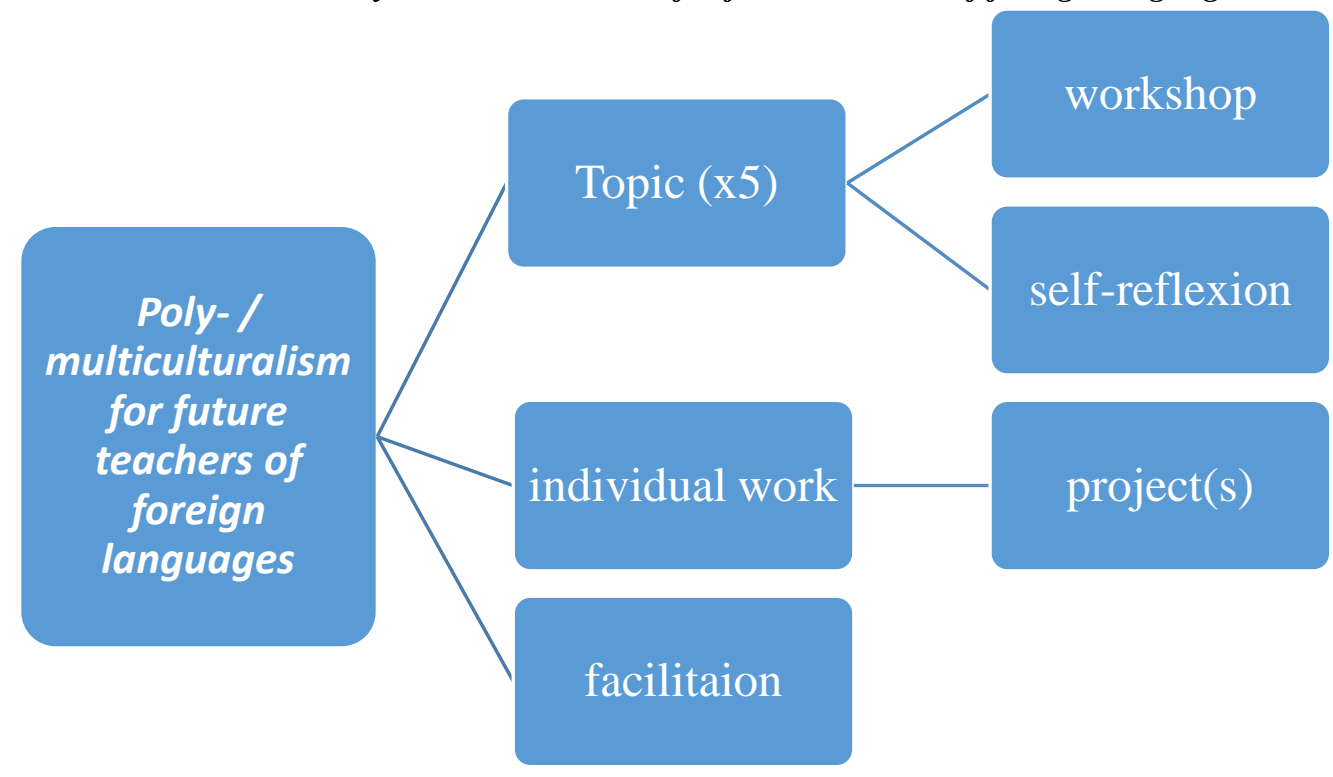

Consequently, the first 5 sections break into 5 topics: (1) Methodological principles for poly- / multicultural upbringing , (2) Modern poly- / multicultural social and educational space, (3) Poly- / multicultural education as a factor in the formation of tolerant relations, (4) Intercultural and ethnic conflicts, (5) Poly- / multicultural educational model as a basis for the formation of Ukrainian civic identity.

The above topics, subsequently, sub-break into two parts, i.e. a relevant workshop and self-reflexion practice. Below is the content part of the topics and their relevant workshops.

Topic 1. Methodological principles for poly- / multicultural upbringing

1. The main categories of pedagogy: education, upbringing, training, socialization.

2. Education as a socio-cultural phenomenon.

3. Culturological and axiological approaches in pedagogy.

Workshop 1. Psychological and pedagogical preconditions and problems of poly- / multicultural education.

1. Linguistic representation of the world (linguistic picture of the world).

2. Linguistic competence.

3. Problems of bilingualism/ polilingualism/multilingualismin society.

Topic 2. Modern poly-/ multicultural social and educational space

1. Culturological approach to education.

2. Humanistic content of poly- / multicultural education.

3. Ethno-pedagogical competence in poly- / multicultural education.

Workshop 2. Modern ethnic representation of the world (ethnic picture of the world).

1. Different types of cultures: European, Asian, Oriental, American, Australian.

2. National culture as a unique culture in the world.

Topic 3. Poly- / multicultural education as a factor in the formation of tolerant relations.

1. The concept of tolerance.

2. Approaches and concepts to poly- / multicultural education and upbringing.

3. The structure of poly- / multicultural competence of the teacher.

4. Means and methods of forming poly- / multicultural education: communication training, special psycho-technical exercises, psychodrama or socio-drama, role-playing, trainings and seminars.

Workshop 3. Tolerance as an integrative quality of personality.

1. Signs of tolerance and intolerance as expressed by a personality.

2. Functions and types of tolerance. 
3. Diagnosis of tolerance.

4. Essential characteristics of the process associated with formation of ethnic tolerance.

5. Ways of forming ethnic tolerance in modern educational practice.

Topic 4. Intercultural and ethnic conflicts.

1. The essence and types of ethnic conflicts. What causes ethnic conflicts?

2. Cultural distance and intercultural conflicts.

3. The content of ethnic conflicts and the specifics of their development.

Workshop 4. The relationship of culture and psychology. Cross-cultural psychology.

1. Types of cultures and subcultures.

2. Cultural pluralism.

3. Norms and rules of conduct in a poly- / multicultural society.

Topic 5. Poly- / multicultural educational model as a basis for the formation of Ukrainian civic identity.

1. Poly- / multicultural educational model.

2. The structure of identity and content of education.

5. Educational technologies in the modern world: their strengths and weaknesses.

Workshop 5. Freedom to express the desired, accounting for each other's opinion in class.

1. Students' design.

2. Students' design.

3. Students' design.

Within the course on "Poly-/multiculturalism for future teachers of foreign languages" title-challenging lectures are regular. These are studied in one area of master's training and do not happen to reveal individually raised issues under the topics of the module. Nevertheless, such lectures analyse the main theories globally and locally, causal links in the whole set of topics of the designated module.

Next, the course anticipates that various types of independent projects are performed, including individual projects, group projects, teamwork; writing essays, after-class feedback as part of reflexive "take-away"; multimedia presentations and short videoclips, etc. All the tasks aim to make students reflect on a regular basis and exercise the new, and grow cultural and linguistic awareness, thus, covering the main issues of the course module.

It is the teacher in class - an FL teacher / instructor, an LSP teacher / instructor, a translation teacher, who designs, introduces, offers and determines types of independent (individual, group or team) work. However, this decision of the teacher follows the agreement with the students, who can always suggest discussing and/or doing something different and offer their own ideas. Students also prepare their creative reports on the performance and implementation of independent engagements in the form of round tables, defence of projects, conferences, role-playing games, workshops, etc., therefore, demonstrating the acquired and/or improved skills on solving professional problems, if any.

Before attending a lecture, students are expected to go over and getting acquainted with the theoretical material from the relevant module and the questions to be discussed in a workshop class.

The first lecture in the course is introductory and explains the logic of studying the module, characterizes the main trends in creative and independent work. The latter embodies in the form of engagements that students may choose for independent performance and the results should be presented in class by the deadline set by the teacher.

Engagements vary and are differentiated according to their complexity level. Workshop classes include interactive forms of learning, creative tasks, projects, going further with research method; teamwork, work in small groups, work in pairs, team / group / individual presentations, etc.

Independent work (independent project) following the choice and abilities of students, under the course, involves such alternative engagements as:

- Writing out from the reference literature the meaning of the requested concepts, e.g. polycultural and multicultural education - and correlating such with personal (student's) understanding;

- Looking up some information (an article, for example) in any media, on the Internet or in scientific periodicals (from 2001 up to the present) on the problems of intercultural communication and preparing a brief overview, including personal thinking;

- Discussing the main problems of cultural and ethnic identity in a poly- / multicultural society;

- Identifying in writing at home or orally in class signs of tolerant and intolerant personality;

- Compiling diagnostic tools for measuring ethnic tolerance;

- Highlighting the 'semantic' property of a national character;

- Filling in the personal portrait and that of each other in class, by using 'other' often used characteristics; 
- Making a list of ten features inherent to the 'typical representative' of the three ethnic communities;

- Writing up at home or discussing in class migrant pedagogy: curricula, programs, methods, problems;

- Preparing a report on "Ethnic tolerance in the Ukrainian media", "The role of ethno-pedagogy in poly- / multicultural education", etc.;

- Highlighting and presenting in a table (diagram) the main differences between individualism and collectivism as cultural syndromes;

- Describing the educational policy in the poly- / multicultural environment in one of Western Europe countries / EMEA region, etc.

It is found that despite the fact all components in the course (relevance, aim and objectives, content and structure, methodology) are significant, it is facilitation part, which makes it work [39]. Facilitation can be carried out at any moment of the course - in the beginning of the module, the beginning of the new topic presented, the beginning of each class - either lecture or workshop, etc.; as a follow-up after the lecture or class; in class at any stage of discussion, argumentation or at a finalising stage. It is critical to collect individual and group opinions after self-reflexion practice and move the discussed into action plan. It is also facilitation.

Finally, when the course moves to an end and it is the session time for credit or examinations, facilitation comes at hand.

It is suggested students start considering credits and exams as facilitation part of looking at their knowledge and skills acquired or improved, rather than assessment. It would change the attitude to such discussions and credit / examination meetings, motivate students to refresh the studied material and encourage them to express their opinions in the light of the learnt.

At the same time, it does not mean teachers may expect students to assume responsibility of designing discussion topics and come up with such on the assessment date. Teachers of foreign languages and LSP teachers / instructors, teachers of translation may prepare the material in advance and suggest going over a number of questions drafted before hand. Under a circumstance students may find questions hard to discuss and elaborate in detail, it is possible to agree on a topic desirable by a student, however, in relation to the core of the course.

Here below is a list of some topics, which may become handy for discussion in class or assessment time, thus, completing a course as facilitation.

\section{Facilitating questions for credit in "Poly- / multiculturalism for future teachers of foreign languages":}

1. Philosophical, sociological and culturological contexts of poly- / multicultural education.

2. Basic concepts of poly- / multicultural education and upbringing.

3. Principles, functions, goals, objectives, and content of poly-/ multicultural education.

4. Ethno-pedagogy as a part of poly- / multicultural education.

5. The relationship of poly-/ multicultural education and international upbringing.

6. The concept of "tolerance": terminology, semantics, categories, functions.

7. Social forms of tolerance.

8. Ethnic tolerance.

9. Tolerance in everyday awareness.

10. Tolerance and religion.

11. International communication as a social need of a poly- / multicultural society.

12. Culture of interethnic (inter-national) communication: forms, structure, content.

13. Language as an element of culture and a means of interethnic (inter-national) communication.

14. Poly- / multicultural dialogue as a factor in the development of a single humanitarian space.

15. Historical background of poly- / multicultural education in the United States and Canada.

16. Western Europe. Pan-European policy. Poly- / multicultural orientation of education in the UK, Germany, France, Belgium.

17. Poly- / multicultural guidelines for educational policy.

18. State policy in the field of education in a poly- / multicultural environment in the Baltics and Eastern Europe.

19. Regulatory and legal basis of poly- / multicultural educational policy of Ukraine.

20. Mono-ethnic schools.

21. Multinational schools.

22. Training of a poly- / multicultural teacher who is training to become a philologist or FL teacher / instructor.

23. Learning expectations of the teacher from the student. Educational cultural style of the student.

24. Migrant pedagogy. Immigrant education. Culture shock.

25. Bi-ethnicity, poly-ethnicity. Bilingual education.

26. The main legislation in the field of poly-/ multicultural education in the United States and Ukraine: comparative approach. 
27. The main legislation in the field of poly- / multicultural education in the United States and Ukraine: contrastive analysis. 28. Goals, objectives, principles of poly- / multicultural education in the United States, the UK, Australia and Ukraine.

29. Poly- / multicultural education in the English-speaking countries and Ukraine.

30. Approaches to developing the content of poly- / multicultural education in the English-speaking countries and Ukraine.

The discussion questions as facilitation part at a credit or exam are for alternative purpose only and may vary from class to class, territory to territory, language to language. For example, if students do German, it is possible to reshape questions and ask students to discuss, compare or contrast approaches to poly- / multicultural education in Germany, Austria, Switzerland, etc. Similarly, it goes for Italy (different regions in Italy, islands, Italian and Maltese, etc.), Spain, Portugal and so on.

\section{CONCLUSION}

Formation of poly- / multiculturalism in national and/or international classrooms may be carried out via implementation in the secondary and tertiary educational institutions of curricula that presuppose a certain focus on global trends, which encompass political, economic, and social developments. Everything influences the culture and language design. Thus, the introduction of a special course in the educational process of training master students that will become future teachers of foreign languages or teachers / instructors of languages for specific purposes, as well as translation teachers, provides the following:

- Development of poly- / multilingual language consciousness of the personality;

- Formation of a system connected with linguistic and cultural knowledge; based on inter-social values;

- Education of socio-cultural tolerance in relation to representatives of other culture(s);

- Development of emotional self-regulation;

- Formation of intercultural communicative competence based on reflexive skills and adequate self-assessment;

- Motivation for constant cultural and spiritual development and self-realization in pedagogical and culturally creative, linguistic and aesthetic activities.

The research findings have already embodied into the design of the course on Poly-/ multiculturalism for future teachers of foreign languages for master students, which is seen from a practice-oriented perspective to bring quality change to the modern educational space. It is realised that more is to be studied and researched. To this part, all and every reasonable critique is highly welcomed and appreciated in advance to everyone, who in interested and may assist and contribute for the further research development (e-mail is above).

\section{REFERENCES}

1) Alonso Alonso, R. (ed., 2016). Crosslinguistic Influence in Second Language Acquisition. Clevedon: Multilingual Matters. Athanasopoulos.

2) Amelina, S. (2008). Problema adekvatnosti v informatyvnomu perekladi. Sotsiokul'turni ta komunikatyvni aspekty funktsionuvannya movnykh odynyts' [The problem of adequacy in informative translation. Sociocultural and communicative aspects of the functioning of language units]: zb. materialiv Mizhnarodnoyi naukovo-praktychnoyi konferentsiyi. Kyyiv: Milenium (in Ukrainian).

3) Antoniuk, R. I. (2004). Tsinnisni oriientatsii u svitli kontseptsii polikulturnoi (interkulturnoi) osvity v Ukraini ta za kordonom Problemy osvity. Kyiv, Vol. 35, p. 40-50 (in Ukrainian).

4) Bakum, Z. P. (2014). Pedahohichni umovy formuvannia profesiinoi kompetentnosti maibutnikh dyzaineriv Naukovi zapysky Ternopilskoho natsionalnoho pedahohichnoho universytetu imeni Volodymyra Hnatiuka. Seriia: Pedahohika. Vol. 1, p. 44-49 (in Ukrainian).

5) Bakum Z., Kostiuk S. (2018). Psychological factors of intercultural competencies development of foreign students in the process of training the Ukrainian language. Association agreement: from partnership to cooperation (collective monograph), ed. M. Dey, O. Rudenko, Hamilton, Ontario, pp. 232-236.

6) Batsevych, F. S. (2004). Fundamentals of Communicative linguistics. Kyiv: Academy (in Ukrainian).

7) Bauer-Wolf, J. (2019). Hate incidents still on the rise on college campuses. Retrieved from https://www.insidehighered.com/news/2019/02/25/hate-incidents-still-rise-college-campuses

8) Bekh, I.D. (2001). Osobystisno-zoriyentovane vykhovannya - nova osvitnya filosofiya [Personality-oriented education - a new educational philosophy]. Pedahohika tolerantnosti [Pedagogy of tolerance], Vol. 1, p. 17 (in Ukrainian).

9) Berry, J. W., \& Kalin, R. (1995). Multicultural and ethnic atti-tudes in Canada. Canadian Journal of Behavioural Science, 27, 310-320. doi:10.1037/0008-400X.27.3.301.

10) Bushkova, V. V. (2001). Osnovni tendentsiyi vzayemodiyi ukrayins'koyi ta amerykans'koyi kul'tur (sotsial'no-filosofs'kyy vymir) [Basic tendencies of interaction of Ukrainian and American cultures (social and philosophical dimension)]: avtoref. dys. na zdobuttya nauk. stupenya kand. filosof. nauk. Kyyiv. (in Ukrainian). 
11) Bukhlova, N. V. (2008). Sutnisnyi zmist poniattia "Samoosvitnia kompetentnist". Naukova skarbnytsia osvity Donechchyny, 1, p. 4 (in Ukrainian).

12) Byram, M. (1997). Teaching and assessing intercultural communicative competence. Multilingual Matters.

13) Chaika (Čajka), O., \& Sharmanova, N. (2021). Paremic Cliches as a Spiritual Layer of Multicultural Communication: Cultivating Respective Values for Educators. International Journal of Social Science and Human Research, Vol. 4 (4), 812-823. DOI: https://doi.org/10.47191/ijsshr/v4-i4-36.

14) Dandy, J., \& Pe-Pua, R. (2010). Attitudes to multiculturalism,immigration and cultural diversity: Comparison of dominant and non-dominant groups in three Australian states. International Journal of Intercultural Relations, 34, 3446.doi:10.1016/j.ijintrel.2009.10.003

15) Dedman, B. (2019). College students are more diverse than ever. Faculty and administrators are not. Retrievedfrom https://www.aacu.org/aacu-news/newsletter/2019/march/facts-figures

16) Dovhan, L., \& Dovhan, Yu. (2016). Peculiarities of Polycultural Education in US Universities. Language, culture and education: proceedings of all-Ukrainian scientific-practical conference of teachers and students / Ed. by H.M. Kaletnyk. Vinnytsia: VNAU, p. 215-217. https://ir.vtei.edu.ua/g.php?fname=26359.pdf (in Ukrainian).

17) Dovhopolova, Ya.V. (2007). Formuvannia tolerantnykh vidnosyn studentiv u polikulturnomu seredovyshchi vyshchoho navchalnoho zakladu : dys. ... kand. ped. nauk Kh. : Kharkiv. nats. un-t im. V.N. Karazina, (in Ukrainian).

18) Dubych, K. V. (2007). Osobystisno oriientovane vykhovannia studentiv v umovakh sotsiokulturnoho seredovyshcha vyshchoho navchalnoho zakladu: dys. ... kand. ped. nauk : 13.00.07 Rivne, (in Ukrainian).

19) Fedotova, V. G. (2011). Yedinstvo mira i mnogoobraziye kul'tur [The unity of the world and the diversity of cultures]. Voprosy filosofii [Philosophy questions], 9, 45-53. URL: http://vphil.ru/index.php?option (in Russian).

20) Giroux, H.A. (1994). Doing the Cultural Studies: Youth and the Challenge of Pedagogy. Harvard Educational Review. Harvard. № 3 (Vol. 64). P. 278-308.

21) Gollnik, D.M. (1990) Multicultural education in a pluralistic society. In D. M. Gollnik \& P. C. Chinn. Columbus, OH : Merrill.

22) Honcharenko, S. \& Nychkalo, N. (ed.) (2000). Profesiina osvita: slovnyk: navch. posib. K.: Vyshcha shkola (in Ukrainian).

23) Jessner, U. (2015). Emerging multilingual awareness in educational contexts: From theory to practice. Canadian Modern Language Review 72(2), 157-182.

24) Kosmeda, T. (2007). Teoriya mizhkul'turnoyi komunikatsiyi v proektsiyi na osobystist' Ivana Franka [The theory of intercultural communication in the projection on the personality of Ivan Franko]. Teoriya i praktyka vykladannya ukrayins'koyi movy yak inozemnoyi [Theory and practice of teaching Ukrainian as a foreign language]. L'viv : Vyd. tsentr LNU im. Ivana Franka, 2, 126-132 (in Ukrainian).

25) Kostiushko, Yu. O. (2005). Pedahohichni umovy pidhotovky maibutnoho vchytelia do mizhosobystisnoi vzaiemodii v sytuatsii konfliktu: dys. kand. ped. nauk : 13.00.04 / Zhytomyr (in Ukrainian).

26) Krasnykh, V. V. (2002). Etnopsikholingvistika i lingvokul'turologiya [Ethnopsycholinguistics and linguoculturology]: kurs lektsiy [a course of lectures]. Moskva: ITDGK «Gnozis» (in Ukrainian).

27) Kuprunova, L. L. (2000). Natsyonalno-rehyonalnbi komponent soderzhanyia obshcheho obrazovanyia $v$ strukture polykulturnoho obrazovanyia: .Razvytye lychnosty v obrazovatelnukh systemakh Yuzhno-Rossyiskoho rehyona. Rostovna-Donu: RHPU (in Russian).

28) Omelko, V. Ye. 1988. Sotsial'naya napravlennost' lichnosti [Social orientation of personality]. Kyiv: Vyshcha shkola (in Russian).

29) Pozhydaieva, O. V. (2012). Pedahohichni umovy pidhotovky maibutnikh sotsialnykh pedahohiv do konsultatyvnoi diialnost. Naukovi zapysky, № 6, Ser. Psykholoho-pedahohichni nauky, p. 133-139 (in Ukrainian).

30) Psykholohichnyi slovnyk / za ped. V. I. Voitka. K.: Vyshcha shkola, 1982 (in Ukrainian).

31) Kolodii, I. ., Byelova, L. ., Aleikseieiva, S. ., Kushnir, V. ., Rudyk, Y. ., \& Kalichak, Y. (2021). A metodologia para a criação de um sistema de informação e análise para controle, planejamento e gestão do processo educacional no HEIS e sua estrutura funcional. Laplage Em Revista, 7(3), p.1-9. https://doi.org/10.24115/S2446-62202021731251p.1-9

32) Samovar, L. A., Porter, R.E., \& McDaniel, E.R. (2010). Communication between cultures. L.A. : Wadsworth : Cengage Learning, $411 \mathrm{p}$.

33) Semenoh, O. (2003). Movne rodynoznavstvo (vykhovnyy potentsial linhvokul'tury ridnoho krayu) [Linguistic family studies (educational potential of linguistic culture of the native land)]. Kyyiv-Hlukhiv: RVV HDPU (in Ukrainian).

34) Sharmanova, N. M. (2015). Etnolinhvistyka [Ethnolinguistics]: navchal'nyy posibnyk / Za red. ZH. V. Koloyiz. Kryvyy Rih : NPP ASTERIKS (in Ukrainian).

35) Shashkova, L. O. (2011). Dialohichnyy vymir sotsial'noyi komunikatsiyi [Dialogic dimension of social communication]. Suchasna ukrayins'ka filosofiya : tradytsiyi, tendentsiyi, innovatsiyi: zbirnyk naukovykh prats' [Contemporary Ukrainian 
philosophy: traditions, tendencies, innovations: a collection of scientific works]. Kyyiv : Vydavnycho-polihrafichnyy tsentr «Kyyivs'kyy universytet» (in Ukrainian).

36) Shevchenko, H. P. (2004). Dukhovnist' i tsinnosti zhyttya. Dukhovnist' osobystosti: metodolohiya, teoriya i praktyka [Spirituality and values of life. Spirituality of personality: methodology, theory and practice]. Luhans'k: Vyd-vo Skhidnoukr. nats. un-tu im. V. Dalya (in Ukrainian).

37) Sidun, L. (2012). Etapy istorychnoho rozvytku polikul'turnoyi osvity v SShA [stages of historical development of polycultural education in the USA]. Scientific Bulletin of Uzhhorod National University, Series "Pedagogy, social work", Vol. 24, p. 148-150 (in Ukrainian).

38) Tadeeva, M. I. (2011). The formation of multilingual and multicultural personality as one of the basic conditions for reforming humanitarian education for sustainable development of society. New pedagogical opinion, Vol. 1, p. 81-84 (in Ukrainian).

39) Tanaka, G. (2002). Higher Education's Self-Reflexive Turn: Toward an Intercultural Theory of Student Development. The Journal of Higher Education, 73(2), 263-296.

40) Tareva, Ye. G. (2013). Mezhkul'turnyy podkhod kak lingvodidakticheskaya innovatsiya [Intercultural approach as a linguodidactic innovation]. Teoriya i praktika obucheniya inostrannym yazykam: traditsii i innovatsii [Theory and practice of teaching foreign languages: traditions and innovations]: sb. statey Mezhdunar. prakt. konferentsii. Moskva : Tezaurus, S. 61-67 (in Russian).

41) Ter-Minasova, S. G. (2008). Yazyk i mezhkul'turnaya kommunikatsiya [Language and intercultural communication]. Moskva : Slovo, (in Russian).

42) Vereshchagin, Ye. M., \& Kostomarov, V. G. (1990). Yazyk i kul'tura: Lingvostranovedeniye v prepodavanii russkogo yazyka kak inostrannogo [Language and Culture: Linguistic and Regional Studies in Teaching Russian as a Foreign Language]. Moskva : Nauka (in Russian).

43) Zelenska, O. (2009). Profesiino znachymi yakosti vykladacha inozemnoi movy u VNZ / Visn. Lviv. un-tu. Ser. Pedahohika, Vyp. 25, Ch. 3. S. 79-86 (in Ukrainian). 